\title{
Originals
}

\section{Current therapeutic management of diabetic nephropathy}

\author{
S. M. Kohler and B. K. Krämer \\ Department of Internal Medicine II, University of Regensburg, Franz-Josef-Strauss-Allee 11, D-93053 Regensburg, Germany
}

Received: 4 January 1993/Accepted in revised form: 28 October 1993

\begin{abstract}
Roughly $40 \%$ of all patients with insulin-dependent diabetes mellitus (IDDM) develop diabetic nephropathy with proteinuria, hypertension and a decrease in glomerular filtration rate 10 to 20 years after the onset of the disease, and 5 years later most patients suffer from end-stage renal disease. Microalbuminuria, defined as an urinary albumin excretion rate (UAER) between 30 and $300 \mathrm{mg} /$ day, strongly predicts the development of nephropathy in IDDM. Nearly all patients with IDDM, a decreasing glomerular filtration rate and a UAER $>300 \mathrm{mg} /$ day have coexisting hypertensive disease additionally worsening renal function. We review the results of recent long-term studies of the current therapeutic management in diabetic patients by means of better blood pressure control, low-protein diet and near-normal blood glucose control in the early microalbuminuric phase as well as in the later phases of the disease characterized by diabetic nephropathy with a UAER $>300$ $\mathrm{mg} /$ day. Since the large majority of studies have been performed on IDDM, our conclusions with regard to therapy are only valid in this subgroup of diabetic patients.
\end{abstract}

Key words: Diabetic nephropathy - ACE inhibitor Protein restriction - Microalbuminuria

\section{Introduction}

Diabetic nephropathy, characterized by proteinuria, hypertension and a decrease in glomerular filtration rate (GFR), occurs in approximately $40 \%$ of insulin-dependent diabetes mellitus (IDDM) patients $10-20$ years after the onset of IDDM [1,2]. Microalbuminuria strongly predicts the development of diabetic nephropathy [3, $4,5]$. Very often patients with IDDM, a decreasing GFR and a urinary albumin excretion rate (UAER) $>300 \mathrm{mg}$ /

Correspondence to: B. K. Krämer day have coexisting hypertensive disease additionally worsening renal function [6]. Diabetic nephropathy is one of the leading causes of end-stage renal disease [7]. Therefore therapeutic regimens to delay or even prevent the development of end-stage renal disease are of great importance. We discuss three different therapeutic approaches to diabetic nephropathy in the microalbuminuric and macroalbuminuric phases of the disease. First, the influence of blood glucose levels on the progression of the disease is considered. Second, the effects of lowprotein diets on GFR and micro- and macroalbuminuria are evaluated. Finally, the role of antihypertensive therapy in normotensive or hypertensive patients with either micro- or macroalbuminuria is discussed.

\section{Blood glucose control}

Blood glucose control in microalbuminuria and diabetes mellitus

Recently a number of long-term studies investigating whether the development of diabetic nephropathy may be prevented or slowed by strict glycaemic control, measured by HbA1 levels, have been published. The Kroc Collaborative Study Group demonstrated a decrease in UAE in patients with a $\mathrm{HbA} 1_{c}$ level of $8.1 \%$ over a period of 8 months. Feldt-Rasmussen et al. studied patients with a $\mathrm{HbA1} 1_{c}$ level of $7.2 \%$ over 2 years and also noted a decrease in albumin excretion. In both studies the group of patients with $\mathrm{HbA}_{\mathrm{c}}$ levels of $8.1 \%$ or $7.2 \%$, respectively, were treated with continuous subcutaneous insulin infusion (CSII). None of the patients in the control group receiving conventional insulin treatment (CIT) showed a significant or sustained improvement in the degree of metabolic control $[8,9,10]$. The Kroc Collaborative Study Group found a decrease in UAER in microalbuminuric patients on CSII with $\mathrm{HbA}_{\mathrm{c}}$ levels of $8.1 \%$ $[8,9]$. In contrast, Feldt-Rasmussen et al. did not observe a decrease in UAER in subjects on CSII, and indeed the rate was unchanged after 2 years of treatment $(170 \mathrm{vs}$ 
$160 \mathrm{mg} / \mathrm{min}$ ). On the other hand, microalbuminuric patients on CIT experienced no change in $\mathrm{HbAl}_{\mathrm{c}}$ and a significant rise in UAER (160 vs $360 \mathrm{mg} / \mathrm{min})$ [10]. Good blood glucose control with $\mathrm{HbA} 1_{\mathfrak{c}}$ levels of $8.1 \%$ or $7.2 \%$ was achieved with CSII (Table 1) $[8,9,10]$. Reichard et al. treated 44 patients with intensified insulin treatment (IIT) for 3 years. The measured $\mathrm{HbA} 1_{\mathrm{c}}$ levels were $7.4 \%$ compared with $9.0 \%$ in the control patients who received regular insulin treatment. The improved blood glucose control of the 44 patients being treated with IIT delayed the development of diabetic nephropathy compared with the control patients receiving regular treatment [11]. In the Steno 1 and Steno 2 studies [12] a total of 51 patients with IDDM and microalbuminuric were followed for 8 and 5 years. In the conventional treatment group an increase in UAER, a decline in GFR and a rise in blood pressure were found only in patients with high microalbuminuria $(100-300 \mathrm{mg} /$ day $)$, whereas in the same subgroup of patients treatment with CSII resulted in a stable UAER and GFR. Analysing the 19 patients with a UAER of $100-300 \mathrm{mg} /$ day, 2 out of 9 in the CSII group progressed to diabetic nephropathy, compared with 10 out of 10 patients in the regular treatment group. Only 1 patient out of 32 with microalbuminuria in the range of 30-99 mg/day developed diabetic nephropathy. Intensive blood glucose control in the Diabetes Control and Complications Trial (DCCT) was associated with a $39 \%$ reduction in the occurrence of microalbuminuria ( $\geq 40 \mathrm{mg} /$ day) and a $54 \%$ reduction in the occurrence of diabetic nephropathy ( $\geq 300 \mathrm{mg} /$ day). In this study 1441 IDDM patients were followed for a median of 6.5 years after random allocation to intensive therapy (external insulin pump or $\geq 3$ daily insulin injections) or to conventional therapy ( $\leq 2$ daily insulin injections) [13].

\section{Blood glucose control with near-normal UAER in diabetes mellitus}

In the 7-year Oslo study [14], 8 out of 10 patients with IDDM and HbA1 levels of $8.5 \%$ showed a decrease in UAER, while 4 out of 14 patients with $\mathrm{HbA} 1$ levels greater than $10 \%$ developed significant increases in UAER to $>200 \mathrm{mg} /$ day. Blood glucose control was achieved by CSII in 10 patients, by IIT in 33 patients and by CIT in 2 patients. All patients participating in the Oslo study had a mean UAER in the upper normal range during the 2 months prior to enrolment in the study (Table 1). Thus, near-normoglycaemic blood glucose levels with $\mathrm{HbA} 1$ levels below $8 \%$ delay the onset of diabetic nephropathy in patients with microalbuminuria and UAER in the upper normal range. It remains unproved whether good glycemic control prevents worsening of renal function in manifest diabetic nephropathy.

\section{Protein restriction}

\section{Effect of protein restriction in diabetic nephropathy}

Low-protein diets improve the haemodynamic situation in the glomerulus and reduce proteinuria in rats with streptozocin (STZ)-induced diabetes. The degree of histological change in diabetic nephropathy is also improved by a low-protein diet $[15,16]$. Walker et al. [17] and Zeller et al. [18] examined the effects of a low-protein $\operatorname{diet}(0.6-0.7 \mathrm{~g}$ protein $/ \mathrm{kg}$ per day) in 19 and 20 patients, respectively, with diabetic nephropathy. The study by Walker et al. had a case-control design. In the study by Zeller et al., 15 patients received a control diet containing at least $1 \mathrm{~g}$ protein $/ \mathrm{kg}$ per day. The follow-up periods were 33 and 37 months, respectively, for the two studies. The patients with a restricted protein intake had a decrease in proteinuria and a reduced decline in GFR (Fig. 1). In another study Brouhard and LaGrone also demonstrated a beneficial effect of a reduced protein intake on GFR and on albuminuria [19]. Evanoff et al. [20] observed eight patients with IDDM, proteinuria (protein excretion $>0.5 \mathrm{~g} /$ day) and renal insufficiency for 12 months before and 12 months after the introduction of dietary protein restriction to $40 \mathrm{~g}$ high biological value protein/day. The creatinine clearance before starting the protein-restricted diet $(55 \pm 27) \mathrm{ml} / \mathrm{min}$ was not significantly different from that after 12 months of the diet (56 $\pm 25 \mathrm{ml} / \mathrm{min}$ ). The mean daily urinary protein excretion

Table 1. Blood glucose control and its effect on UAER and GFR in diabetes mellitus

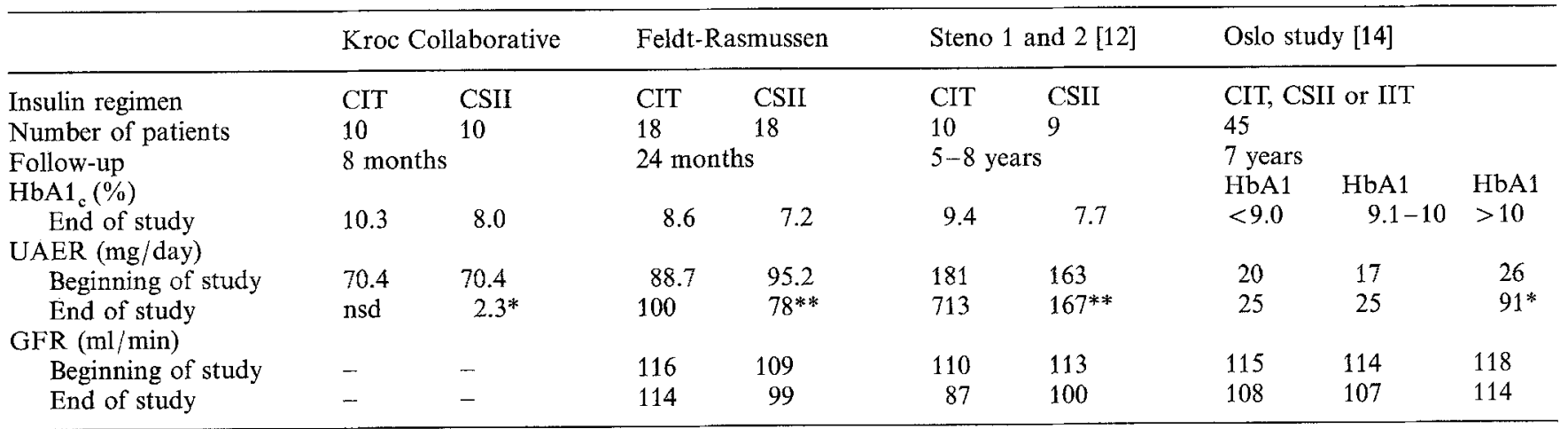

CIT, Conventional insulin treatment; CSII, continuous subcutaneous insulin infusion; ITT, intensified insulin treatment; nsd, no significant decline

* Significant difference between beginning and end of study $(P \leq 0.02)$

** Significant difference between CIT and CSII at end of study $(P \leq 0.002)$ 
fell from $2.11 \pm 1.36 \mathrm{~g} /$ day before dietary protein restriction was started to $0.14 \pm 0.16 \mathrm{~g} /$ day after 12 months of the diet. In a later study [21], Evanoff et al. followed 11 IDDM patients suffering from proteinuria $(>0.5 \mathrm{~g} /$ day $)$ and renal insufficiency on a diet containing $0.6 \mathrm{~g} / \mathrm{kg}$ per day high biological value protein for 2 years. In a similar manner to the earlier 12-month study, creatinine clearances at 12 and 24 months of protein restriction were not significantly different from those obtained at the beginning of the low-protein diet. Urinary protein excretion again decreased after the initial 12 months to $0.57 \pm 0.40$ $\mathrm{g} /$ day compared with $2.27 \pm 0.49 \mathrm{~g} /$ day at the beginning of the study. However, after 24 months of the low-protein diet urinary protein excretion increased to $1.43 \pm 0.63 \mathrm{~g} /$ day. According to the authors, one reason for this phenomenon might have been non-compliance with the dietary regimen, expressed as higher urea nitrogen concentrations in urine samples.

\section{Effect of protein restriction on GFR and microalbuminuria}

In a crossover study lasting only 3 weeks, Cohen et al. observed a decrease in UAER to $22 \mathrm{mg}$ /day in eight nor-

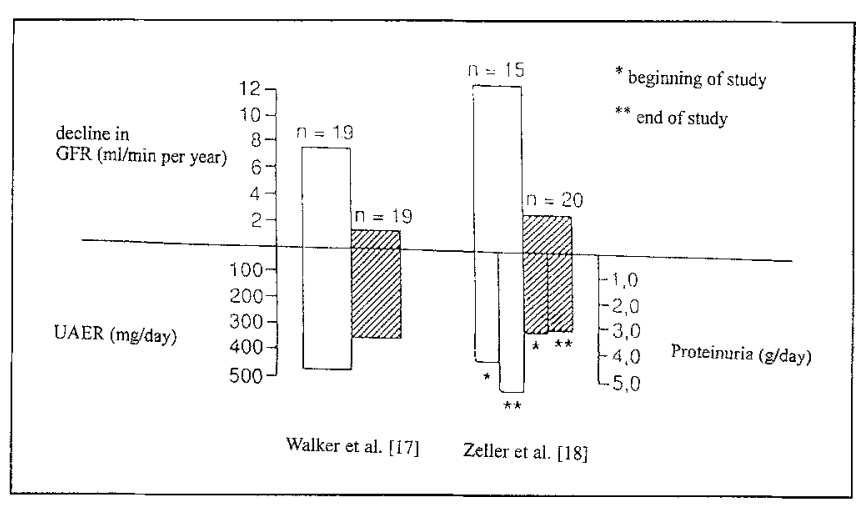

Fig. 1. Decline in UAER and diminished loss of GFR with lowprotein diet $(0.6-0.7 \mathrm{~g} / \mathrm{kg}$ per day). Open bar, control group; filled bar, treatment group motensive patients with IDDM and microalbuminuria who received a low-protein diet of $38-57 \mathrm{~g}$ protein/day. A protein intake of $55-117 \mathrm{~g} /$ day resulted in UAER of $33 \mathrm{mg} /$ day [22]. The results of this study imply that a low-protein diet causes a reduction in UAER even in the microalbuminuric phase of the disease. Long-term studies with a larger number of patients are required to determine the stage of disease (microalbuminuria versus nephropathy) at which protein restriction should be started.

\section{Role of antihypertensive therapy}

\section{Normotension and microalbuminuria in diabetes mellitus}

In a randomized, placebo-controlled, double-blind study of 20 patients, of whom 10 suffered from NIDDM, microalbuminuria and normotension and the other 10 from IDDM, microalbuminuria and normotension, Marre et al. demonstrated that the ACE inhibitor enalapril $20 \mathrm{mg} /$ day induced a significant decrease in UAER during the first 6 months of treatment. None of the diabetics in the treatment group developed diabetic nephropathy, whereas three patients in the placebo group progressed to diabetic nephropathy during the complete follow-up of 1 year [23, 24]. However, the mean arterial pressure was reduced by enalapril administration (Table 2). It is not clear whether the decrease in mean arterial pressure or the vasodilating effect of the ACE inhibitor at the vas efferens was responsible for the noted decrease in microalbuminuria [23, 24]. The Melbourne Study Group followed 43 diabetic patients for 1 year, of whom 30 were normotensive and 13 hypertensive, and 19 suffered from IDDM and 24 from NIDDM [25]. In the subgroup of patients with IDDM or NIDDM, microalbuminuria and normotension there was no significant change in UAER under treatment with either perindopril or nifedipine. None of these patients progressed to diabetic nephropathy. In the 13 hypertensive subjects also suffering from

Table 2. Normotension and microalbuminuria in diabetes mellitus

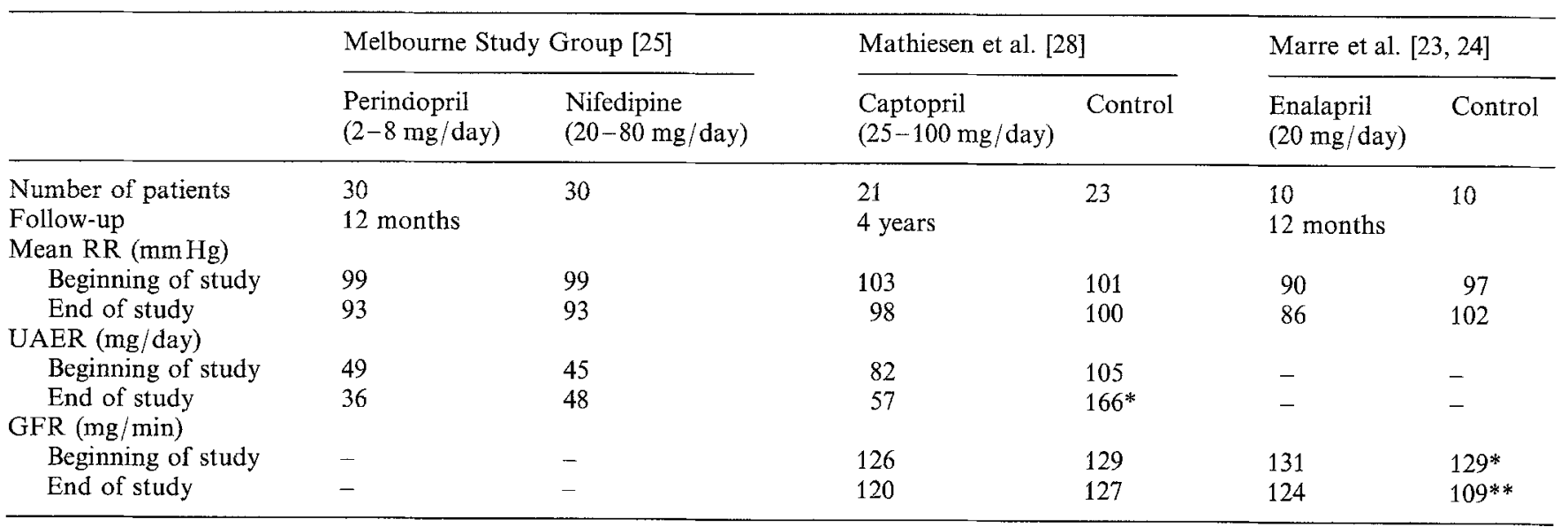

* Significant difference between two treatment groups at end of study $(P<0.05)$

** Significant difference between beginning and end of study $(P<0.05)$ 
IDDM or NIDDM and microalbuminuria, both treatments reduced UAER significantly (Table 2). Cook et al. found a significant decrease in UAER during 3 months of ACE inhibitor therapy with captopril in 12 normotensive adolescents [26]. Another short-term study lasting 6 weeks [27] showed a $40 \%$ decrease in UAER during captopril treatment compared with a $40 \%$ increase during nifidepine treatment and no change in UAER in the placebo group. The study population comprised microalbuminuric patients with IDDM randomly assigned to one of the two treatment groups or to the placebo group. In a 4-year prospective randomized, controlled study of 44 normotensive patients with microalbuminuria and IDDM [28], captopril $25-100 \mathrm{mg} /$ day with the addition of bendrofluazide $2.5 \mathrm{mg}$ /day after 30 months resulted in a decrease in UAER. During this long-term study none of the patients in the treatment group progressed to diabetic nephropathy, whereas seven patients in the placebo group developed diabetic nephropathy with a UAER of $>300 \mathrm{mg} /$ day (Table 2). The above-mentioned results suggest a positive effect of ACE inhibition on renal function in patients with microalbuminuria and normotension.

\section{Hypertension and microalbuminuria in diabetes mellitus}

Patients with diabetes mellitus and microalbuminuria often suffer from high blood pressure in the further course of their disease. Christensen and Mogensen observed a correlation between the duration of the disease and the degree of microalbuminuria, as well as between the elevation of diastolic blood pressure and the worsening of microalbuminuria [29]. Gambardella et al. treated ten patients with NIDDM, hypertension and microalbuminuria with indapamide $2.5 \mathrm{mg} /$ day for 2 years [30]. Microalbuminuria significantly decreased. Two studies have compared the effects of an ACE inhibitor and a calcium antagonist in hypertensive patients with diabetes mellitus and microalbuminuria: $2-8 \mathrm{mg}$ /day perindopril vs $20-$ $80 \mathrm{mg} /$ day nifedipine in 13 IDDM and NIDDM patients for 12 months [25]; $10-20 \mathrm{mg} /$ day enalapril vs $60-120$ $\mathrm{mg} /$ day nicardipine in seven IDDM patients for 4 weeks [31]. No significant differences in terms of lowering of blood pressure, decrease in microalbuminuria and GFR could be shown between the two types of agents $[25,31]$. In contrast, Pedersen et al. observed a further decline in UAER after adding an ACE inhibitor to the antihypertensive regimen in ten patients with IDDM [32]. Antihypertensive treatment is valuable in patients with microalbuminuria and hypertension. In animal studies ACE inhibitors have been shown to be superior to other antihypertensive agents, but as far as we know, long-term studies proving superiority of ACE inhibitors over conventional antihypertensive therapy in humans are lacking, although as stated above short-term studies demonstrate that the addition of an ACE inhibitor to antihypertensive therapy has a favourable effect on UAER.

\section{Normotension and diabetic nephropathy}

Parving et al. [33] found that 15 normotensive IDDM patients with nephropathy treated with an ACE inhibitor (captopril 25-100 $\mathrm{mg} /$ day) for 12 months showed a decrease in mean arterial pressure of $3 \mathrm{~mm} \mathrm{Hg}$, in UAER of $11 \%$ and in GFR of $3 \mathrm{ml} / \mathrm{min}$ per $1.73 \mathrm{~m}^{2}$, while the 17 untreated control patients showed an increase in mean arterial pressure of $6 \mathrm{~mm} \mathrm{Hg}$, an increase in UAER of $55 \%$ and a decrease in GFR of $6 \mathrm{ml} / \mathrm{min}$ per $1.73 \mathrm{~m}^{2}$. Although the rate of decline in GFR was not statistically significant in this study, the results suggest that treatment of patients with still-normal blood pressure and diabeticnephropathy with an ACE inhibitor might reduce the rate of or prevent the decline in GFR.

\section{Hypertension and diabetic nephropathy}

Diabetic patients with nephropathy have a $50-70 \%$ risk of developing hypertension, often resulting in a further decline in renal function [1]. In the first long-term study of a small group of patients with IDDM, proteinuria and high blood pressure treated with propanolol and later with metoprolol (100-200 mg/day), a diminished loss of GFR and a decrease in proteinuria was found in treated patients. Three and four, respectively, of the six patients were additionally treated with $40 \mathrm{mg} /$ day frusemide and 100-200 mg/day hydralazine [34]. Good blood pressure control achieved with metoprolol, hydralazine and frusemide was shown to slow the decline in GFR and reduce proteinuria in 11 patients with IDDM, nephropathy and high blood pressure. This study lasted for 6 years [35], and a follow-up to a total of 9.7 years confirmed the results in the same 11 patients [36]. The rate of the decline in GFR decreased from $10.7 \mathrm{ml} / \mathrm{min}$ per year before treatment to $2.5 \mathrm{ml} / \mathrm{min}$ per year during antihypertensive therapy. UAER fell from $1.5 \mathrm{~g} /$ day to $0.8 \mathrm{~g} /$ day [36]. In another study, Parving et al. treated 18 hypertensive patients with nephropathy with the ACE inhibitor captopril and a diuretic frusemide or bendrofluazide. During the 2.5 years of follow-up UAER decreased and a reduced decline in GFR was noted (Fig. 2) [37]. Björk et al. used an antihypertensive therapy combining an ACE inhibitor (captopril), a diuretic, a beta-blocker and a calcium antagonist [38]. Mean arterial blood pressure was lowered by $5 \mathrm{~mm} \mathrm{Hg}$ and the decline in renal function was slowed in all 14 patients (Fig. 2). Björk et al. thus confirmed the beneficial impact of ACE inhibition on UAER and GFR. In a 2-year follow-up, 22 of 40 IDDM patients with diabetic nephropathy were treated with $5-20 \mathrm{mg} /$ day enalapril and the other 18 patients received up to $200 \mathrm{mg} /$ day metoprolol [39]. A diuretic was added to the treatment of both groups. The rate of decline in GFR was $2.0 \mathrm{ml} / \mathrm{min}$ per year in the enalapril group and $5.6 \mathrm{ml} / \mathrm{min}$ per year, a surprisingly high value, in the metoprolol group. UAER was $60 \%$ lower in the enalapril group. The supine diastolic blood pressure was $6 \mathrm{~mm} \mathrm{Hg}$ lower in the enalapril group, whereas the standing mean arterial pressure did not differ significantly between the two treatment groups. In the group treated with enalapril one patient had a rise in serum creatinine and was withdrawn from the study. However, a superior effect on GFR of an ACE inhibitor compared with a beta-blocking agent could not be confirmed in a study by Grönhagen-Riska 


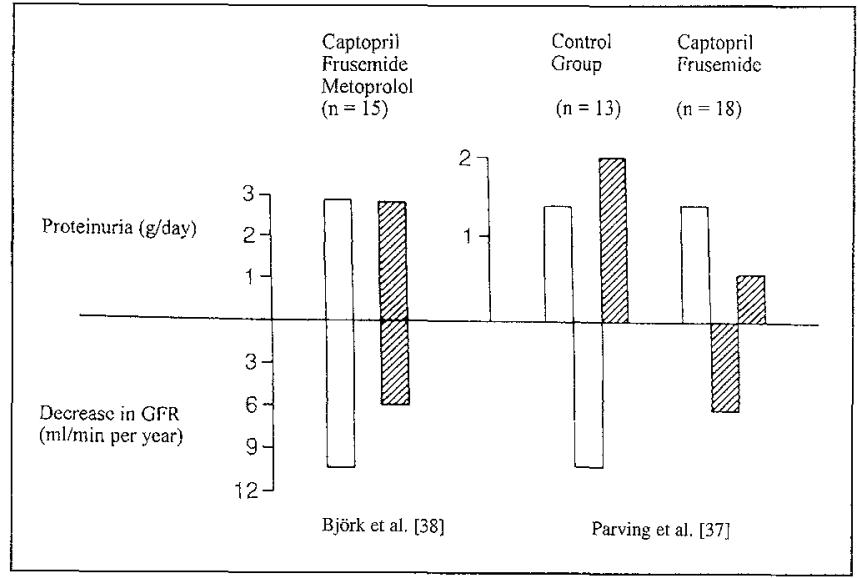

Fig. 2. Effects of antihypertensive treatment on proteinuria and GFR in patients with diabetic nephropathy. Open bar, before therapy; filled bar, after therapy

et al. [40]. In a recent study by Lewis et al., 409 IDDM patients were followed up for a median of 3 years in a randomized controlled trial. 207 patients (155 hypertensive) received $3 \cdot 25 \mathrm{mg} /$ day of captopril and 202 patients (153 hypertensive) received placebo. Doubling of serum creatinine and the combined endpoints of death, dialysis and transplantation were significantly higher in the placebo group. However blood pressure control was better, GFR as baseline higher and protein excretion lower in the captopril group [41]. Therapy to normalize blood pressure slows the progression of renal disease in manifest diabetic nephropathy, but study results so far have not demonstrated a clear superiority of any one class of antihypertensive agents (e.g. ACE inhibitors).

\section{Future trends and perspectives in treating diabetic nephropathy}

In animal models thromboxane (TX) A2 seems to be of relevance in the pathogenesis of diabetic nephropathy. In a controlled study the effects of the dietary administration of the TX synthetase inhibitor OKY -046 on urinary protein excretion and serum BUN were evaluated in 20 STZ-induced diabetic rats [42]. The treated group developed a urinary protein excretion of $64.1 \mathrm{mg} /$ day compared with $85.6 \mathrm{mg} /$ day in the control group. The treated rats also showed a reduced thickening of the glomerular basement membrane, lower serum glucose levels and normalization of enhanced platelet aggregation, but no significant differences in the serum BUN levels of the treated and control groups were found. Unfortunately the GFR was not studied. No side effects of OKY-046 have been reported. It might therefore be a promising therapy in humans as well, but further evaluation is clearly needed.

In experimental diabetes using STZ diabetic rats, the administration of indomethacin an inhibitor of prostaglandin synthesis, leads to an increase in the afferent arteriolar hydraulic resistance and a moderate increase in the efferent resistance causing a reduction in the hydraulic pressure in the glomerular capillaries [43]. In a small randomized double-blind trial the effects of 150 $\mathrm{mg} /$ day indomethacin for 3 days were studied in $8 \mathrm{pa-}$ tients with IDDM and microalbuminuria, who were compared with a placebo group of 9 normoalbuminuric IDDM patients and 11 healthy controls [44]. Indomethacin caused a significant reduction in UAER (from 207 to $87 \mathrm{mg} /$ day) and in prostaglandin E2 urinary excretion (from 317 to $103 \mathrm{pg} / \mathrm{ml}$ ), which was elevated compared with two control groups not suffering from microalbuminuria. GFR remained stable. In a more recent study the beneficial effect of indomethacin on exercise-induced UAER in IDDM with microalbuminuria was confirmed [45]. Of the 14 patients with IDDM studied, 9 suffered from microalbuminuria at rest and 5 were normoalbuminuric. The patients were treated in a randomized cross-over design with a single oral dose of indomethacin, metoprolol or placebo shortly before exercising. The rise in UAER in the microalbuminuric patients receiving indomethacin was lower than in those receiving placebo or metoprolol (7, 29 and $18 \mu \mathrm{g} / \mathrm{min})$. Although the results of animal studies and short-term evaluations in small groups of patients are promising, the long-term influence of prostaglandin synthesis inhibitors on diabetic nephropathy is not yet known.

Some investigators have suggested the polyol-sorbitol pathway to be of major importance in the development of diabetic nephropathy. Oates et al. demonstrated a dosedependent reduction in UAER in STZ-induced diabetic rats being treated with zopolrestat, an aldose-reductase inhibitor [46]. With a dose of $100 \mathrm{mg} / \mathrm{kg}$ the elevated UAER was reduced by $77 \%$. In a short-term doubleblind, cross-over study aldose reductase inhibition with $600 \mathrm{mg} /$ day polanrestat given for 3 months to 28 microalbuminuric IDDM patients decreased UAER significantly compared with placebo $(37 \mathrm{mg} /$ day decrease vs $16.5 \mathrm{mg} /$ day increase) [47].

Although, as mentioned above, ACE inhibitors so far have not been proven to be superior to other antihypertensive agents in delaying the decline in renal function in patients with microalbuminuria in long-term studies, the treatment of diabetic uninephrectomized rats before microalbuminuria was present with the ACE inhibitor, fosinopril, markedly limited the development of progressive albuminuria after 8 months of diabetes, compared with control groups receiving either nifedipine or no antihypertensive agent. The value for UAER in the ACE inhibitor group was $32 \mathrm{mg} /$ day, for the nifedipine group $136 \mathrm{mg} /$ day and $113 \mathrm{mg} /$ day for the group without antihypertensive therapy [48]. The positive effect of ACE inhibition on the development of microalbuminuria has also been conformed in another animal study [49]. Based on these animal trials it could be the case that patients with IDDM may profit from the administration of an $\mathrm{ACE}$ inhibitor even before microalbuminuria has developed.

A positive effect of dipyridamole on the UAER of patients suffering from diabetes mellitus has been reported [50]. In 27 patients suffering from NIDDM an increase in the $U_{\mathrm{abb}} / \mathrm{U}_{\text {creat }}$ ratio of 0.80 per month was found over an observation period of 10.8 months. After the observation period 11 patients with a $\mathbf{U}_{\mathrm{alb}} / \mathrm{U}_{\text {creat }}$ ratio of 
$>1.0$ were treated with $50 \mathrm{mg}$ dipyridamole three times daily for 4.2 months. A decrease in the $U_{\text {alb }} / U_{\text {creat }}$ ratio of 0.36 per month was found. Four of the patients were on insulin, the others were taking oral antidiabetics. Another 15 patients without a prior observation period and a $\mathrm{U}_{\mathrm{alb}} / \mathrm{U}_{\text {creat }}$ ratio $>1.0$ received the same amount of dipyridamole for 9 months, resulting in a decrease in the $\mathrm{U}_{\mathrm{alb}} / \mathrm{U}_{\text {creat }}$ ratio of 0.43 per month. Unfortunately the authors did not record the daily albumin excretion to demonstrate the effect of dipyridamole on UAER. Furthermore, untimed urine samples were taken. It is therefore difficult to compare the above results with those of other study regimens, and further, more standardized evaluations of dipyridamole in diabetic nephropathy are needed.

\section{References}

1. Hasslacher C, Ritz E, Hypertonie and diabetes mellitus. Internist (Berlin) 31:180-190, 1990

2. Kleophas W, Voitz T, Messner H, Gries FA, Diabetische Nephropathie. Fortschr Med 108:309-312, 1990

3. Mogensen CE, Microalbuminuria as a predictor of clinical diabetic nephropathy. Kidney Int 31:673-689, 1987

4. Mogensen CE, Microalbuminuria predicts clinical proteinuria and early mortality in maturity onset diabetes. New Engl J Med 310: $356-360,1984$

5. Viberti GC, Jarrett RJ, Mahmud U, Hill RD, Argyropoulos A, Keen $H$, Microalbuminuria as a predictor of clinical nephropathy in insulin-dependent diabetes mellitus. Lancet I: 1430-1432, 1982

6. Steffes MW, Mauer SM, Diabetic nephropathy: a disease causing and complicated by hypertension. Clin Chem 37/10 (B): $1838-1842,1991$

7. Eggers PW, Effect of transplantation on the Medicare end-stage renal disease program. New Engl J Med 318:223-229, 1988

8. The Kroc Collaborative Study Group, Blood glucose control and the evolution of diabetic retinopathy and albuminuria. New Engl J Med 311:365-372, 1984

9. The Kroc Collaborative Study Group, Collaborative studies of the effects of continuous subcutaneous insulin infusion in insulin-dependent diabetes mellitus. Diabetes 34 [Suppl 3]: 8789,1985

10. Feldt-Rasmussen B, Mathiesen ER, Deckert T, Effect of two years of strict metabolic control on progression of incipient nephropathy in insulin-dependent diabetes. Lancet II: 1300 1304, 1986

11. Reichard P, Rosenquist U, Nephropathy is delayed by intensified insulin treatment in patients with insulin-dependent diabetes mellitus and retinopathy. J Intern Med 226:81-87, 1989

12. Feldt-Rasmussen B, Mathiesen ER, Jensen T, Lauritzen T, Deckert $T$, Effect of improved metabolic control on loss of kidney function in type I (insulin-dependent) diabetic patients: an update of the Steno studies. Diabetologia 34:164-170, 1991

13. The Diabetes Control and Complications Trial Research Group, The effect of intensive treatment of diabetes on the development and progression of long-term complications in insulin-dependent diabetes mellitus. New Eng1 J Med 329:977986, 1993

14. Dahl-Jörgensen K, Björk T, Kierulf P, Sandvik L, Bangstad HJ, Hanssen KF, Long-term glycemic control and kidney function in insulin-dependent diabetes mellitus. Kidney Int 41:920-923, 1992

15. Hostetter TH, Olson JL, Rennke HG, Venkatachalam MA, Brenner BM, Hyperfiltration in remnant nephrons: a potentially adverse response to renal ablation. Am J Physiol 241:F85F93, 1981

16. Wen S-F, Huang T-P, Moorthy AV, Effects of low protein diet on experimental diabetic nephropathy in the rat. J Lab Clin Med 106:589-597, 1985
17. Walker JD, Bending JJ, Dodds RA, Mattock MB, Murrells TJ, Keen $\mathrm{H}$, Viberti GC, Restriction of dietary protein and progression of renal failure in diabetic nephropathy. Lancet II: 1411 1415,1989

18. Zeller K, Whittaker E, Sullivan L, Raskin P, Jacobson HR, Effect of restricting dietary protein on the progression of renal failure in patients with insulin-dependent diabetes mellitus. New Engl J Med 324:78-84, 1991

19. Brouhard $\mathrm{BH}$, LaGrone L, Effect of dietary protein restriction on functional renal reserve in diabetic nephropathy. Am J Med $89: 427-431,1990$

20. Evanoff GV, Thompson CS, Brown J, Weinmann EJ, The effect of dietary protein restriction on the progression of diabetic nephropathy. Arch Intern Med 147:492-495, 1987

21. Evanoff GV, Thompson CS, Brown J, Weinmann EJ, Prolonged dietary protein restriction in diabetic nephropathy. Arch Intern Med 149:1129-1133, 1989

22. Cohen D, Dodds R, Viberti G, Effect of protein restriction in insulin dependent diabetics at risk of nephropathy. BMJ 294: 795-798, 1987

23. Marre M, Chatellier G, Leblanc H, Guyene TT, Menard J, Passa P, Prevention of diabetic nephropathy with enalapril in normotensive diabetics with microalbuminuria. BMJ 297: 1092-1095, 1988

24. Marre M, Leblanc H, Suarez L, Guyenne T-T, Menard J, Passa $P$, Converting enzyme inhibition and kidney function in normotensive diabetic patients with persistent microalbuminuria. BMJ 294:1448-1452, 1987

25. Melbourne Diabetic Nephropathy Study Group, Comparison between perindopril and nifedipine in hypertensive and normotensive diabetic patients with microalbuminuria. BMJ 302: $210-216,1991$

26. Cook J, Daneman D, Spino M, Sochett E, Perlman K, Balfe JW, Angiotensin converting enzyme inhibitor therapy to decrease microalbuminuria in normotensive children with insulindependent diabetes mellitus. J Pediatr 117:39-45, 1990

27. Mimram A, Insua A, Ribstein J, Bringer J, Monnier L, Comparative effect of captopril and nifedipine in normotensive patients with incipient diabetic nephropathy. Diabetes Care 10: $850-853,1988$

28. Mathiesen ER, Hommel E, Giese J, Parving H-H, Efficacy of captopril in postponing nephropathy in normotensive insulindependent diabetic patients with microalbuminuria. BMJ 303: 81-87, 1991

29. Christensen $\mathrm{CK}$, Mogensen CE, The course of incipient diabetic nephropathy: studies of albumin excretion and blood pressure. Diabetic Med 2:97-102, 1985

30. Gambardella S, Frontoni S, Felici MG, Spallone VB, Gargiulo $P$, Morano S, Menzinger G, Efficacy of antihypertensive treatment with indapamide in patients with noninsulin-dependent diabetes and persistent microalbuminuria. Am J Cardiol 65: $46 \mathrm{H}-50 \mathrm{H}, 1990$

31. Baba T, Murabayashi S, Takebe $\mathrm{K}$, Comparison of the renal effects of angiotensin converting enzyme inhibitor and calcium antagonist in hypertensive type II (non-insulin-dependent) diabetic patients with microalbuminuria: a randomised controlled trial. Diabetologia 32:40-44, 1989

32. Pedersen MM, Hansen KW, Schmitz A, Sorensen K, Christensen CK, Mogensen CE, Effects of ACE inhibition supplementary to beta blockers and diuretics in early diabetic nephropathy. Kidney Int 41:883-890, 1992

33. Parving H-H, Hommel E, Nielsen MD, Giese J, Effect of captopril on blood pressure and kidney function in normotensive insulin dependent diabetics with nephropathy. BMJ 299:533536, 1989

34. Mogensen CE, Long term antihypertensive treatment inhibiting progression of diabetic nephropathy. BMJ 285:685-688, 1982

35. Parving H-H, Andersen AR, Smidt UM, Hommel E, Mathiesen ER, Svendsen PA, Effect of antihypertensive treatment on kidney function in diabetic nephropathy. BMJ 294: 1443-1447, 1987 
36. Parving H-H, Smidt UM, Mathiesen ER, Hommel E, Ten year experience with antihypertensive treatment in diabetic nephropathy. Diabetologia 34 [Suppl 2]: A38, 1991

37. Parving H-H, Hommel E, Smidt UM, Protection of kidney function and decrease in albuminuria by captopril in insulin dependent diabetics with nephropathy. BMJ 297:1086-1091, 1988

38. Björk S, Nyberg G, Mulec H, Granerus G, Herlitz H, Aurell M, Beneficial effects of angiotensin converting enzyme inhibition on renal function in patients with diabetic nephropathy. BMJ 293: 471-474, 1986

39. Björk S, Mulec H, Johnsen SA, Norden G, Aurell M, Renal protective effect of enalapril in diabetic nephropathy. BMJ 304: $339-343,1992$

40. Grönhagen-Riska C, Honkanen E, Metsärinne K, Rosenlöf K, Tikkanen I, Fyhrquist F, ACE-inhibition versus conventional antihypertensive treatment ( $\beta$ blockade) in diabetic nephropathy. Am J Hypertens 3:67A, 1990

41. Lewis EJ, Hunsicker LG, Bain R, Rohde RD, The effect of angiotensin-converting-enzyme inhibition on diabetic nephropathy. New Engl J Med 329:1459-1462, 1993

42. Hora K, Oguchi H, Furukawa T, Hora K, Tokunaga S, Effect of a selective thromboxane synthetase inhibitor OKY -046 on experimental diabetic nephropathy. Nephron 56:297-305, 1990

43. Jensen PK, Steven K, Blaehr H, Christiansen JS, Parving H-H, Effects of indomethacin on glomerular hemodynamics in experimental diabetes. Kidney Int 29:490-495, 1986
44. Mathiesen ER, Hommel E, Olsen UB, Parving H-H, Elevated urinary prostaglandin excretion and the effect of indomethacin on renal function in incipient diabetic nephropathy. Diabetic Med 5:145-149, 1987

45. Rudberg S, Sätterströ G, Dahlquist R, Dahlquist G, Indomethacin but not metoprolol reduces exercise-induced albumin excretion rate in type 1 diabetic patients with microalbuminuria. Diabetic Med 10:460-464, 1993

46. Oates PJ, Ellery CA, Davis KM, Guzzie DN, Inskeep PB, A1dose reductase inhibitor Zopolrestat dose-dependently reduces albuminuria in streptozocin-diabetic rats. Diabetes 42 [Suppl 1]: 157 A, 1993

47. Blohme G, Smith U, Aldose reductase inhibition reduces urinary albumin excretion rate in incipient diabetic nephropathy. Diabetologia 32:476A, 1989

48. Anderson S, Rennke HG, Brenner BM, Nifedipine versus fosinopril in uninephrectomized diabetic rats. Kidney Int 41:891897,1992

49. Zatz R, Dunn BR, Meyer TW, Anderson S, Rennke HG, Brenner BM, Prevention of diabetic glomerulopathy by pharmacological amelioration of glomerular capillary hypertension. $\mathrm{J}$ Clin Invest 77:1925-1930, 1986

50. Aizawa T, Suzuki S, Asawa T, Komatsu M, Shigematsu S, Okada N, Katakura M, Hiramatsu K, Shinoda T, Hashizume K, Takasu N, Yamada T, Masaoka Y, Mimura M, Takahashi H, Shimizu K, Honda Z, Dipyridamole reduces urinary albumin excretion in diabetic patients with normo- or microalbuminuria. Clin Nephrol 33:130 -135, 1990 